\title{
Hearing child of Deaf parents in speech and language therapy intervention and a potential obstacles in current practise
}

\author{
Štěpánka Lauková1, Martina Hoffmannová
}

\section{Abstract}

The following case study would like to describe the speech and language intervention provided to the child of Deaf parents (CODA) and possible obstacles that the therapist could face during the intervention process. There would be also introduced the plan to deliver the intervention based on current evidence - based standards in healthcare settings. Furthermore, there would be described approach which was used to incorporate parents of the child even through the language barrier. Lastly the case study could also well described the use of the sign language interprator in pre and post intervention process while sharing the information with parents. Although the CODA children might be just a fraction of the Deaf community members, there are interesting facts that could possibly apply to other focus groups in the Deaf community. Lastly as there is not any standardize way how to deal of CODA children in the speech and language intervention or source of the potential best practice guidelines the case study could have used.

\section{Keywords}

child of Deaf parents, CODA, speech and language therapy intervention, speech and language therapist, sign language, evidence - based methods, questionnaire, parents, bilingualism

\section{Introduction}

Hearing children of Deaf parents are referred to by the abbreviation CODA. This acronym means Children of Deaf Adults. In 1983, an international organization of the same name was established in California to make sure this information about Deaf families would be more popularized to mainstream society. Once a year, the organization would organize an international conference where members could meet. The first meeting took place in Fremont in 1986. CODA has the largest number of members in the USA (Horáková, 2011). CODA members capture a relatively small linguistic and cultural group (Horáková, 2012; Horáková, 2011). In the Czech Republic, in 2008, the civic association CODA was founded - hearing descendants of deaf parents, o.s., which is inspired by the ideas of the American organization and tries to bring togetherness to CODA individuals and allow them to meet together and create a sense of belonging. One aspect of people who consider themselves CODA may be the prerequisites for bilingualism. By meeting both spoken and sign languages from childhood, it is easier and more natural for them to move seamlessly from one language to another. Most Deaf parents often deal with their children's first language during their upbringing. Parents are concerned about whether it is good to teach such children to sign when the sign language is actually parenting only for their parents, or whether they should adopt spoken language instead, because they are hearing and can thus communicate with the ordinary hearing society.

Redlich (2008) argues that children under the age of six should associate with both sign language and Czech spoken language. Sign language is spoken by parents, who should not use spoken language. Průcha

1 Štěpánka Lauková, Masaryk University, Brno, Czech Republic

2 Martina Hoffmannová, Univerzita Hradec Králové, Hradec Králové, Czech Republic 
(2011) deals with whether bilingualism is beneficial to individuals or not, and states that if a child learns languages inadvertently, such bilingualism is beneficial for the child. Often, CODA individuals in adulthood become professional interpreters. They speak sign language well and are used to moving around in the Deaf community. They are also well-known in many cases to help their parents, so they are close to helping professions. As a professional, however, he must avoid making decisions on behalf of the client and only translate. They're used to their parents basically taking responsibility for them. Therefore, an individual should be educated in this field so that he/she can become a truly professional interpreter (Redlich, 2008). Another specific element of CODA for children is, for example, awareness of differences. One striking feature is the different tone of the voice and the visible signage between the parent and the child when communicating. Redlich (2008) states that the offspring do not want to communicate with their parents, for example, in the 1990s public transport, precisely because of a conspicuous and different communication system.

The problem can also arise if parents attend clubs or associations for the Deaf and take their children who do not speak sign language well with them. This can result in deprivation from the fact that the child cannot fully communicate with others. For example, a hearing child of Deaf parents may have trouble adjusting to a different world. Furthermore, it may happen that he hears about cultural customs later than his classmates. Such habits include, for example, intense and frequent to touch of other and unknown people, knocking on doors or pointing fingers at other people. It is also possible to include these people where the social situation does not allow it, e.g. a teacher at school (Strnadová, 2002). Bucino, 1990 has stated the the most important fact during the councelling session e.g. therapy session is to establish which parent is primary user of sign language and which parent is able to act as an interpreter. Often there is the case that only one parent is able to use the sign language on the mother tongue level. De Melo, 2015 in his study about CODA children in Brazil describes, that it was found that "the older Deaf people knew sign language and even had the opportunity to know the main institutions of the country connecting them to the Deaf community; however, the younger ones did not know it, they learned through coexistence" (Melo, 2015). In the Czech Republic it is common practice to use the interpretations service which is fully funded by government and it is one of the many social services that are available to Deaf community members. Also the CODA child in the speech and language intervention might not be very common, it is good to establish the clear and structured way of the intervention routine.

\section{Case Presentation}

\section{Background information}

The following case study would like to introduce a three-year-old boy who is the child of Deaf parents which the acronym CODA is used for. At first there would be described the speech and language therapy intervention step - by - step and also the cooperation with the sign language interpreter and furthermore Special Education Centre (which is local Special Education authority in Czech Republic). The main scope of Special Education Centre is to diagnose and to deliver the educational support in place during the child's education.

\section{Description of the presenting problem}

The boy's family background information: both parents identify themselves as members of Deaf community, the grandparents from mother's side are both Deaf, but there is an aunt who is hearing, therefore the sign language so as spoken language were used in the household. Both parents from the father's side identifies themselves as members of Deaf community and in the household the sign language was used without any spoken language. Boy's mother finished the compulsory education and later on has taken apprenticeship as a seamstress. Boy's father has taken an apprenticeship as a locksmith. The parents are married and there are no other siblings in the household.

Personal history: The boy was born from the mother's first pregnancy, the birth took place at 39 weeks of gravidity, the Apgar score was 10-10-10. The psychomotor development of the boy was following the milestones within the expected time. He has sat down without support around seven months, he crawled around the ninth month, around eleventh month he began to walk slowly with support of the nearby furniture. 
The main mode of communication at home was sign language, both parents used it so as boy's grandparents. Therefore, the boy has had the opportunity to use spoken language only during the visits of local playground. During the regular pediatric check-up, it was suggested to start the speech and language therapy and the boy was referred to the clinical speech therapy ambulance due to a delay in speech development.

The first visit took place in September 2018, during the entire session the sign language interpreter was present and interpreter the entire session. The first session took almost two hours. The time was the biggest obstacle. From the therapist point of view, it was quit challenging to lead the diagnostic session, make a notes, talk to parents via interpreter and also try not to lose boy's attention, as his attention span was quite short. During the session it was rather obvious that in order to capture the whole process it would be great to record it and later analyze the boy's interactions and usage of sign language versus spoken language and also gestures with meaning.

It was also decided to connect parents with Special Education Centre, which is local authority and try to get assessment and potentially also support of teaching assistant at the preschool settings. There was a great opportunity that with the support of the teaching assistant the boy's vocabulary and understanding would be developing much faster. As the preschool setting was really one opportunity to give some spoken language role models such as teacher, teaching assistant and classmates.

Another finding from the first therapy session were visible difficulties that the boy has manifested short-term intentional attention, as well as frequent changes in interest and activities, which may have been result of sign language environment (as the communication in sign language is often here and now).

The diagnostics of speech perception shown that the boy operated within the 30 moths level, he was able to choose correct object and activity according the verbal instruction, he understand the prepositions such as in, to, under, on. The boy was able to identify basic colours. During the first session he preferred to use gestures rather than spoken language.

The speech expressive skills have shown some one word answers to the questions, he named the introduced farm animals correctly, he was able to answer the questions such as Who? What? Where? he has shown that he worked within the 30 moths level of expressive skills. During the therapy session the parent questionnaire was used. This questionnaire is called Short Questionnaire of the Children's Dictionary (SDDS) in Smolík, 2021, and is used to determine the level of the conceptual dictionary. In the case of this boy, the entry level of spoken language speech expression was 14/40 words, speech perception: 22/40 words, which has shown significant deficit. However in the data provided by parents that establish the level of sign language the results were different the speech or sign expression was 31/40 and the sign perception 40/40. As far as speech expressive skills in spoken language the boy manifests the skills significantly unevenly, for example, he did not yet respond to nursery rhymes, but he did not complete the rhyme, he didn't use the possessive pronouns of mine, yours, only me or shows with a gesture. The graphomotor skills diagnostics shown that the boy preferred to use right hand, he drew the basic doodles with meaning. The visual perception skills level in entry diagnostics showed that the boy operated within 36 months level, which was the strongest skill. He was able to fold halfimages and shapes separately, the matched the colours correctly. As a result of the first session it was recommend to establish close cooperation with the kindergarten and regularly cooperate with the teacher's assistant to create a conceptual dictionary, but also to develop the intentional attention of the boy, auditory perception skills and continue to monitor the development of the spoken language.

\section{Working with Plan}

As stated above, at the very first session it was decided to record the responses of the boy in order to capture most of the progress during each session.

As Brackenbury, Ryan, Messenheimer, (2006) described in their single case study the both languages such as ASL and spoken English are being learned simultaneously, infant hearing children of two Deaf adults are most likely to acquire ASL as their dominant language, as a result of their parent's input, and spoken English as a subordinate language from in the environment, such as grandparents or neighboroughs. This reflects the L1-L2 relationship. In addition, even though one language is dominant, these children receiving consistent exposure to both languages within naturalistic contexts. 
In the following sessions it was quite obvious that the increase of the sign language has been more prominent, as the boy has spent most of the time exposed to the sign language. The expressive level of spoken Czech was slowly picking up particularly in the area of the naming objects that the boy might have been exposed during the time in the preschool setting (such as toothbrush, crayon, roll).

\section{Management and Outcome}

Throughout the year the total number of four additional session took place. During these it was measured the use of the gestures, signs of Czech Sign language and also expressive level of spoken language. Prior to each session the boy's parents also fill in the Short Questionnaire of the Children's Dictionary (SDDS) for the signs that the boy was using at home. The preschool teaching assistent that was assign to boy has fill in the spoken language words in the Short Questionnaire of the Children's Dictionary (SDDS), this allowed to track the vocabulary in both languages. The words from the questionnaire were used as a word group target in the intervention. There was clear preference to use the sign language from the boy's side, even though there were no actual users of sign language.

During the session the series of activities that consisted the words from the questionaire were set up, and the therapist was tracking the responses of the boy. The therapy sessions were mainly focused on the developing of the understanding and building up the vocabulary. One of the targets of each session was also to prolong the attention span in choosen activities in order to increase it. After each sesssion the progress or main points were communicated to parents via interpretor and also shown on recordings and explained. Therefore the time for the session has almost doubled.

\section{Discussion}

The presented case study has shown the possibility of the use of the parent's questionnaire in the speech and language therapy session while tracking the development of language during the therapy process. This allowed to track the progress of each language development and also record the vocabulary and present it across the different settings such as preschool, healthcare provider and home setting. Another interesting part was to observe how in bilingual background of the one language becomes dominant and how even there are education support measures it is still the personal choice and preference to use the dominant language throughout the session. Furthermore, the case study has highlighted the possible obstacles in the providing therapy session such as time allowance or the need to establish the good and clear communication mode with the preschool settings so the boy's language development could be evolving. It was also interesting to see how much time was dedicated for interpreting the therapy outcomes from each session to parents.

\section{Conclusion and implications}

Although the presented case study consisted only from five consecutive sessions some practical guidelines has arisen from the experience. Firstly, it is necessary to establish some sort of routine and communication mode prior to meeting with the parents who are the members of Deaf community in order to get as many information across. While using interpreter it is necessary to allow more time for each session. The recording of the session would be also additional option as the therapist can illustrate the task or progress that was achieved during the therapy session. It there are two languages in place, it is great to track the progress while using the parent's questionnaire that could be later on check for the progress. It was also shown how the language that the child was exposed most was becoming more dominant. At the end of the year there were recommend for example some team played afterschool activities that would expose boy to more spoken language community. Lastly the link between the therapist and the preschool setting was also quite beneficial as it allowed the both parties to keep the track of the language exposure and exposure to various tasks in order to increase the level of spoken language.

\section{References}

1. Brackenbury, T., Ryan, T., \& Messenheimer, T. (2006). Incidental word learning in a hearing child of deaf adults. Journal of deaf studies and deaf education, 11(1), 76-93.

2. Buchino, M. A. (1990). Hearing children of deaf parents: A counseling challenge. Elementary School Guidance \& Counseling, 24(3), 207-212. 
3. de Melo, A. V. S., \& de Melo, A. V. S. (2015). Children of deaf adults: CODAS em Sergipe. Interfaces Científicas-Educação, 3(3), 77-86.

4. Horáková, R. (2011). Surdopedie. Texty k distančnímu vzdělávání. Paido.

5. Horáková, R. (2012). Sluchové postižení: úvod do surdopedie. PORTÁL sro.

6. Průcha, J., (2011). Dětská řeč a komunikace: Poznatky vývojové psycholingvistiky. Grada Publishing as.

7. Redlich, K. (2008).CODA-slyšící děti neslyšících rodičů. Česká komora tlumočníků znakového jazyka.

8. Smolík, F., \& Bytešníková, I. (2020). Screening poruch jazykového vývoje v raném věku: přehled a představení dotazníku SDDS. Czecho-Slovak Pediatrics/Cesko-Slovenska Pediatrie, 75(8).

9. Smolík, F., \& Bytešníková, I. (2021). Validity of the SDDS: A 40-item vocabulary screening tool for 18-to 42-month olds in Czech. Journal of Communication Disorders, 106146.

10. Strnadová, V. (2002). Úvod do surdopedie. Technická univerzita, Pedagogická fakulta, Katedra pedagogiky a psychologie. 